\title{
Idiopathic Pulmonary Fibrosis: From Epithelial Injury to Biomarkers - Insights from the Bench Side
}

\author{
Keren Borensztajn ${ }^{a-d}$ Bruno Crestani ${ }^{a-d}$ Martin Kolb ${ }^{e}$

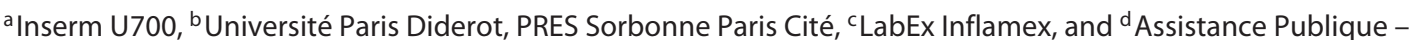 \\ Hôpitaux de Paris, DHU FIRE, Service de Pneumologie A, Hôpital Bichat, Paris, France; e Department of Medicine, \\ Firestone Institute of Respiratory Health, St. Joseph's Healthcare, Hamilton, Ont., Canada
}

\section{Key Words}

Biomarkers · Epithelial injury · Fibrosis · Idiopathic pulmonary fibrosis $\cdot \mathrm{KL}-6 \cdot$ Parenchymal lung disease . Surfactant proteins

\begin{abstract}
Idiopathic pulmonary fibrosis (IPF) is the most frequent fibrotic diffuse parenchymal lung disease. Its prognosis is devastating: $>50 \%$ of the patients die within 3 years after diagnosis. Options for the treatment of IPF are limited and lung transplantation is the only 'curative' therapy. Currently, in the absence of validated indicators of disease progression/ activity and diagnostic tools, the clinical management of IPF remains a major challenge. A better understanding of the pathogenesis of IPF is critical for the identification of new therapeutic targets as well as molecules that may serve as surrogate markers for clinically significant endpoints. The current paradigm on the mechanisms leading from a normal to a fibrotic lung postulates that chronic epithelial lesion leads to aberrant wound healing activation, which is characterized by deregulated fibroblast proliferation and activation together with an uncontrolled extracellular matrix synthesis. In this review, we shed light on the role of epithelial cell damage in the pathogenesis of fibrosis. Finally, we exam-
\end{abstract}

ine the markers of epithelial damage and their potential use as biomarkers and the future of this continuously expanding field.

(c) 2013 S. Karger AG, Basel

\section{Introduction}

Pulmonary fibrosis constitutes the end stage of a broad range of heterogeneous interstitial lung diseases (ILDs), which are characterized by the destruction of pulmonary parenchyma together with deposition of extracellular matrix (ECM) in the interstitial and alveolar spaces. Idiopathic pulmonary fibrosis (IPF) is the most frequent fi-

Previous articles in this series: 1. Cottin V, Camus P: Practical issues and challenges in idiopathic pulmonary fibrosis. Respiration 2013;86:1-4. 2. Poletti V, Ravaglia C, Buccioli M, Tantalocco P, Piciucchi S, Dubini A, Carloni A, Chilosi M, Tomassetti S: Idiopathic pulmonary fibrosis: diagnosis and prognostic evaluation. Respiration 2013;86:5-12. 3. Kenn K, Gloeckl R, Behr J: Pulmonary rehabilitation in patients with idiopathic pulmonary fibrosis - a review. Respiration 2013;86:89-99. 4. Antoniou KM, Wells AU: Acute exacerbations of idiopathic pulmonary fibrosis. Respiration 2013;86:265-274. 5. Jones MG, Fletcher S, Richeldi L: Idiopathic pulmonary fibrosis: recent trials and current drug therapy. Respiration 2013;86:353-363.

\section{KARGER}

E-Mail karger@karger.com

www.karger.com/res
(C) 2013 S. Karger AG, Basel

0025-7931/13/0866-0441\$38.00/0
Prof. Bruno Crestani

Service de Pneumologie A, Hôpital Bichat

46 rue Henri Huchard

FR-75877 Paris Cedex 18 (France)

E-Mail bruno.crestani@bch.aphp.fr 
brotic diffuse parenchymal lung disease. Its prognosis is devastating: $>50 \%$ of the patients die within 3 years after diagnosis. As implicit by its name, IPF is characterized by the absence of an identified cause and a distinct histopathological pattern of usual interstitial pneumonia. Other salient histological features of IPF include honeycombing, sparse cellular inflammation and areas of fibroblast and myofibroblast accumulation and proliferation, known as fibroblastic foci [1]. Options for the treatment of IPF are limited and lung transplantation is the only 'curative' therapy. To date, only pirfenidone, an orally administered pyridine derivative, has been approved in the EU for the treatment of mild-to-moderate IPF, although more data on overall survival and quality of life on treatment are still needed to fully appreciate its potential clinical benefits [2].

Diagnosing and managing IPF remains a challenge in daily practice [3]. The ATS/ERS (American Thoracic Society/European Respiratory Society) international consensus statement on IPF in 2000 [4], updated in 2011 [5], and the ATS/ERS reclassification of ILDs in 2002 [6], updated in 2013 [7], constitute a real progress in the clinical understanding of IPF. These documents provided clinicians with powerful tools and led during the last decade to a better characterization of the IPF disease phenotype, resulting in diagnostic improvements and an unprecedented number of clinical trials [8]. However, in the absence of a gold standard, the diagnosis of IPF often requires a multidisciplinary approach between clinician, radiologist and pathologist [5]. The establishment of a confident or a consensus diagnosis of IPF is not the only challenge. The clinical course of individual patients with IPF is highly variable and unpredictable. IPF is not a uniform clinical dynamic disease: there is a wide spectrum of disease courses, including stability/slow progression over a period of years, rapid deterioration or even periods of relative stability punctuated by events of rapid decline [9]. Currently, in the absence of validated indicators of disease progression/activity and diagnostic tools, the clinical management of IPF remains a major challenge, although some useful clinical scores, such as the GAP score (based on gender, age and physiological data), which relate to prognosis evaluation, are emerging [10].

A better understanding of the pathogenesis of IPF is critical for the identification of new therapeutic targets as well as molecules that may serve as surrogate markers for clinically significant endpoints. Although significant advances in the understanding of the pathogenesis of IPF have been made during the past decades, the exact mechanisms underlying the development of IPF remain large- ly unknown [1]. It has long been believed that lung fibrosis was preceded and provoked by a chronic inflammatory process that injures the lung and modulates fibrogenesis, leading to end-stage fibrotic scarring. This model provided a rational basis for the use of anti-inflammatory agents such as corticosteroids and immunosuppressive agents. However, inflammation is never a prominent histopathological finding in usual interstitial pneumonia, and there is little evidence of prominent inflammation in early disease. Recently, the PANTHERIPF clinical trial was conducted to assess the safety and efficacy of the triple anti-inflammatory regimen of prednisone, azathioprine and $\mathrm{N}$-acetylcysteine. However, the results of this randomized, double-blind, placebo-controlled trial revealed increased risks of death and hospitalization in treated patients compared to the placebo arm of the study [11]. Therefore, these results support the concept that inflammation is not the leading cause of fibrogenesis during IPF.

These observations led Selman et al. [12] to challenge the model of inflammation-driven fibrogenesis and to shift to another pathogenic paradigm (fig. 1). In 2001, they proposed that IPF is the result of aberrant wound healing responses following repetitive epithelial injury. This model was built on histological observations. Adjacent to fibroblastic foci, there are prominent alterations in the alveolar epithelium, including hyperplasia and denudation [13-15]. Several animal models demonstrated similar defects [16-18]. Fibroblast differentiation and collagen production in vitro is enhanced in epithelial cell/ fibroblast cocultures by injury to the epithelial cell component [19]. The potential importance of the alveolar epithelium in IPF pathogenesis is further highlighted by the observation that epithelial cell growth factors are decreased in patients with IPF $[20,21]$ and that those factors protect against scarring in animal models [22-24]. Finally, targeted injury of alveolar epithelial cells (AEC) consistently induces pulmonary fibrosis in experimental models [25]. Based on these observations, the corollary of this new paradigm is that IPF is an 'epithelial-fibroblastic disease', i.e. a fibroproliferative disorder preceded by alveolar epithelial injury and activation, with fibroblastic foci representing the primary sites of injury and aberrant repair. However, one should be aware that this is the prevailing concept and that it does not necessarily reflect the whole picture. New data and evidence may emerge and shift the thinking to a new concept in the future. Myofibroblasts in turn provoke basement membrane disruption and promote AEC apoptosis, perpetuating the damage and preventing subsequent re-epithelialization. The 


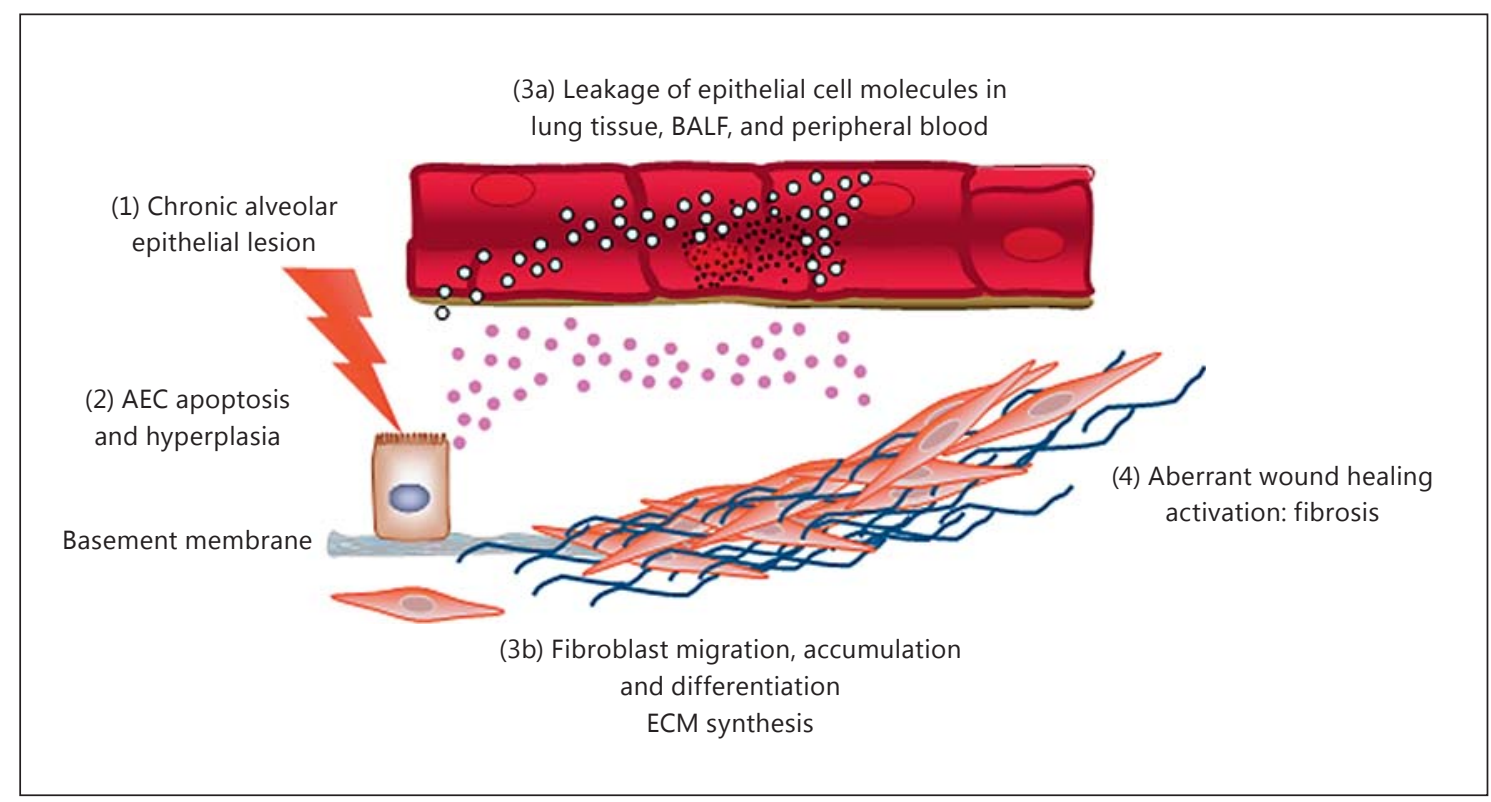

Fig. 1. Model for the contribution of epithelial cell injury in pulmonary fibrogenesis. Chronic AEC injury (1) leads to epithelial cell damage characterized by dysregulated apoptosis and hyperplasia (2). In the fibroblastic foci, fibroblasts differentiate into myofibroblasts (3a); basement membrane disruption and epithelial cell apoptosis, perpetuating the damage and preventing subsequent re- epithelialization. The final result is the excessive deposition of ECM with destruction of the alveolar-capillary units (3a). On the other hand, leakage of molecules derived from damaged epithelial cells into the lung tissue or plasma may serve as a biomarker to monitor the disease course or prognosis (3b). final result is the excessive deposition of ECM with destruction of the alveolar-capillary units and formation of cystic fibrotic spaces lined with abnormal epithelial cells of alveolar or bronchiolar origin in honeycombing areas [26].

In this review, we will highlight the potential contribution of AEC to IPF pathogenesis. We will first briefly discuss the role of normal epithelium in normal lung repair and homeostasis, and the mechanisms leading to epithelial injury and their consequences. Next, we will present how markers of epithelial damage can be used to monitor disease activity. Finally, we will discuss the future of this continuously expanding field.

\section{AEC in Physiological Lung Repair and Homeostasis}

Understanding the mechanisms of lung repair and homeostasis after injury represents one of the major mysteries of pulmonary biology. The lung is extremely complex, and both its development and its repair require interaction of $>40$ different cell types [for an excellent review, see ref. 27]. A functioning, intact alveolar epithelium is in- volved in ion transport and production of surfactant, and serves as a physical barrier, and all of them are necessary to maintain pulmonary homeostasis and fluid balance.

The alveolar epithelium consists of alveolar type I (AECI) and type II cells (AECII). The flat AECI cover $>90 \%$ of the alveolar surface area. The attenuated cytoplasm provides for close approximation of the alveolar lumen and the bloodstream, optimizing respiratory gas exchange. The cuboidal AECII are multifunctional cells and play a crucial role in lung homeostasis. These cells are important for active alveolar liquid clearance. They are also involved in the metabolism of surfactant, which allows breathing at normal transpulmonary pressures by reducing surface tension. The surfactant proteins (SP)-B and SP-C are key components of surfactant. SP-A and SP-D are compounds of the innate immune defense system which are able to bind to the surface of pathogens, thereby facilitating their removal by alveolar macrophages [28-30]. AECII act as facultative progenitors, with the ability to replace themselves and to differentiate into AECI after injury [31]. In line, in the model of bleomycininduced pulmonary fibrosis, intratracheal instillation of a purified population of syngeneic AECII cells was suffi- 
cient to block fibrotic lung remodeling [32, 33]. It is likely that it is this central role of AECII in lung homeostasis which makes them vulnerable to injury, with the risk of promoting undesirable responses, such as fibrosis or apoptosis. Pulmonary fibrosis may be a disease resulting from exhaustion of the pool of alveolar epithelial stem cells resulting in failure of repair. This general scheme nicely integrates the notion of genetic predisposition to the disease resulting from telomerase mutations and the evidence that familial and sporadic IPF is associated with shorter telomeres in blood cells and AEC [34-36].

\section{Contribution of Epithelial Cell Injury to IPF}

An early and consistent feature of IPF is a change in the AEC phenotype. These changes include increased apoptosis associated with regenerative hyperplasia, differentiation of mucus cells in the distal airspaces during a process called bronchiolization and enhanced proliferation [12]. Apoptosis of AECs during IPF has been the subject of extensive research and is now well established. There are several triggers of AEC apoptosis, and most attention has been given to Fas activation, the role of reactive oxygen species and TGF- $\beta$ (for an excellent review on the mechanisms of epithelial apoptosis, see Jin and Dong [37]). Irrespective of the triggers, there is a plethora of mechanisms by which AEC injury can drive aberrant cell cross talk and fibrogenesis. It is possible that epithelial cells undergo transdifferentiation into fibroblast epithelial-mesenchymal transition (EMT). During EMT, epithelial cells lose their characteristic markers (for instance E-cadherin) and acquire mesenchymal markers such as a-smooth muscle actin $[38,39]$. In murine models of bleomycin-induced pulmonary fibrosis, several elegant lineage-tracing studies have suggested that EMT is a potential source of myofibroblasts during fibrogenesis, with up to $30 \%$ of pulmonary fibroblasts arising from EMT [40]. In contrast, one lineage-tracing study suggested no evidence for EMT, although the authors speculated that differences in the experimental setup could explain these differences [41]. Another hypothesis is that damage of AECII can lead to the loss of control exerted by AECII on fibroblast proliferation and collagen synthesis. For instance, AECIIs are an important source of prostaglandin $E_{2}$, which has been shown to inhibit multiple aspects of the fibroproliferative response, including fibroblast chemotaxis, proliferation and collagen synthesis [42-44]. A loss of AECII could diminish intra-alveolar levels of this antifibrotic mediator. It has been shown recently that prostaglandin $\mathrm{E}_{2}$ deficiency results in increased AEC but reduced fibroblast sensitivity to apoptosis in IPF [45]. Moreover, it has been shown that chronically injured AEC release a number of profibrotic compounds, such as tissue factor, factor VII and factor X, which are all able to activate mesenchymal cells $[46,47]$. It is also possible that apoptotic AECII release factors such as CCL2 or CXCL12 and attract circulating fibrocytes, which may locally expand the fibroblast pool $[48,49]$. The relative importance of each individual mechanism in pulmonary fibrogenesis remains to be defined. Importantly, these different mechanisms are not mutually exclusive, and all potentially may drive potent fibroproliferative responses [50].

\section{Monitoring the Disease: Insights from the Bench Side}

It seems straightforward that epithelial cell damage, as well as aberrant scar formation, will lead to the liberation and/or exposure of molecules in the lung tissue, bronchoalveolar lavage fluid (BALF) or even in peripheral blood, which can reflect the presence of the disease. Several of these proteins and cells can be considered as attractive biomarkers, at least if they are found in serum or BALF and can be obtained in a noninvasive manner. By definition, a biomarker indicates a change in the expression or state of a biologic measurement (for instance, the levels of a protein in the serum) at a given time point that correlates with the risk or progression of a disease, or with the susceptibility of the disease to a given treatment at a future time point [51-53]. A biomarker acts as surrogate (i.e. an endpoint expected to predict clinical benefit, lack of benefit or harm based on epidemiologic, therapeutic, pathophysiological or other scientific evidence [53]) for clinically meaningful outcomes, and may or may not reflect the pathogenesis underlying a disease. That is, it may be a crucial contributor to disease pathogenesis, and as such constitute both a biomarker and a target, or just be an epiphenomenon. In IPF, an ideal biomarker should be reliable, valid, responsive to changes in disease status, able to show a clinically meaningful difference, predictive of clinical outcome and responsive to the treatment effect of a given intervention. Such meaningful biomarkers could be used as (1) diagnostic biomarkers to establish a confident diagnosis of IPF and allow discriminating between IPF and other idiopathic or nonidiopathic ILDs; (2) prognostic biomarkers that are correlated with disease progression or mortality, and (3) biomarkers that can be used as tools for serial monitoring of disease severity in longitudinal studies. Finally, given the number of thera- 
Table 1. Principal findings obtained from clinical studies conducted on the indicated targets as potential biomarkers

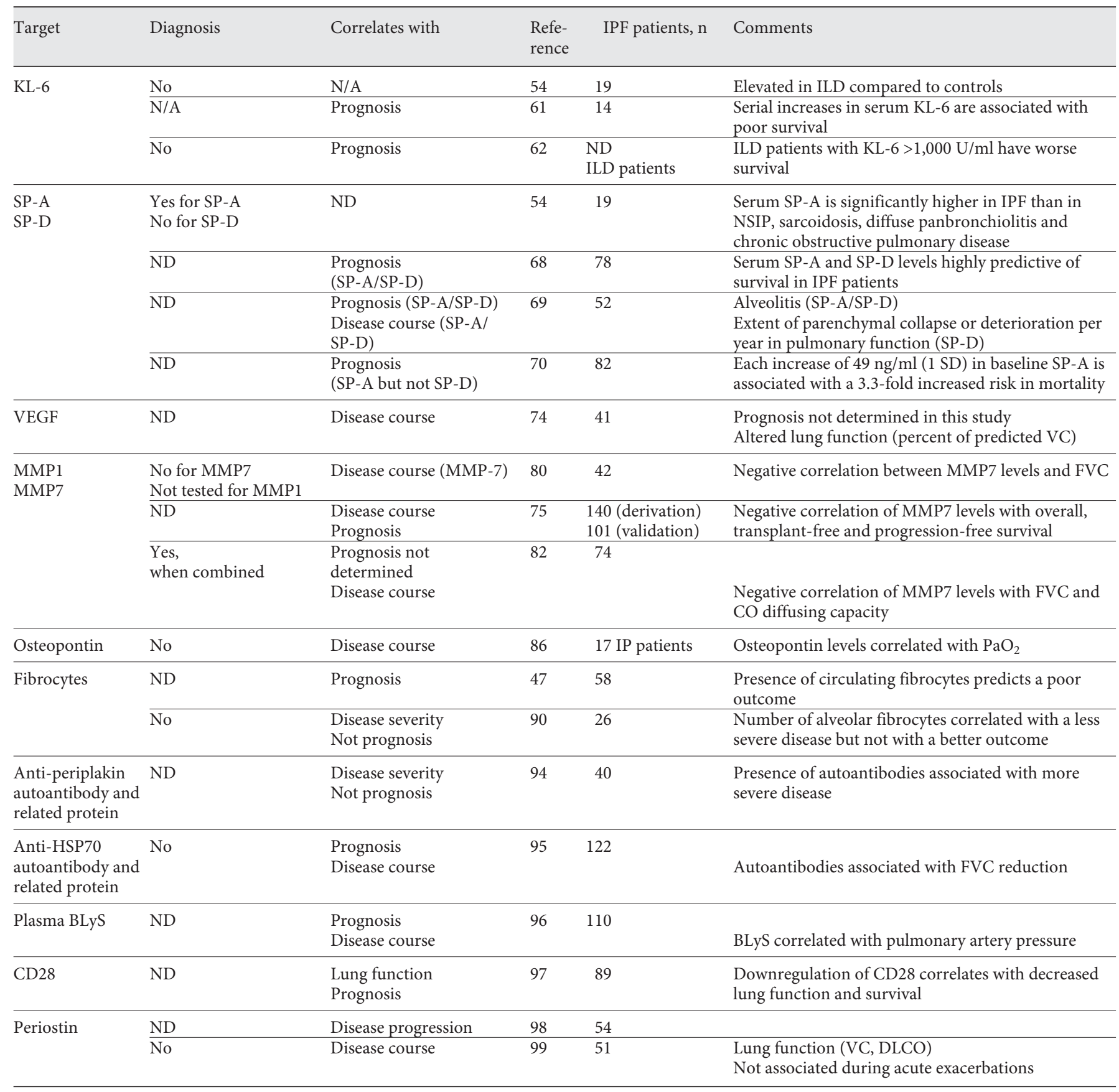

BLyS = B lymphocyte-stimulating factor; FVC = forced vital capacity; IP = interstitial pneumonia; ND = not determined; NSIP = nonspecific IP; VC = vital capacity.

peutic trials in IPF, the identification of specific and sensitive biomarkers would also be crucial to evaluate the efficacy of new treatment regimens [51-53]. Special attention has been given to the peripheral blood protein markers. They present advantages over the other com- partment as they are minimally invasive and readily available in clinical settings, and can easily be measured longitudinally and during exacerbations (for excellent review on the different types of pulmonary biomarkers and existing limitations, see Doyle et al. [54]). 
Over the last 2 decades, a plethora of serum markers was tested regarding their use in IPF. Among them, the most promising are a range of molecules involved in epithelial damage and repair, inflammation, myofibroblast accumulation and ECM deposition. Table 1 summarizes the findings obtained from clinical studies conducted on these molecules with respect to diagnosis, prognosis and monitoring of the disease course. Exhaustive analysis of biomarkers linked to other cell compartments and/or ECM can be found in a study by Vij and Noth [55]. Reviewing these biomarkers in their whole would fall beyond the scope of this article.

\section{Krebs von den Lungen-6 Antigen}

Krebs von den Lungen- 6 antigen (KL-6), otherwise known as MUC1, is a mucin-like glycoprotein expressed at the extracellular surface of various epithelial cells, including regenerating AECII [56]. Upon epithelial damage, KL-6 may leak into the circulation where it can be measured in the serum. In IPF patients, serum KL-6 levels are elevated compared to healthy volunteers [57]. Because KL-6 promotes human pulmonary fibroblast migration and proliferation [58], it can be hypothesized that changes in KL-6 levels are not only an epiphenomenon, but may play a role on the progression of the disease. KL-6 is not useful for the diagnosis of IPF as it is also elevated in patients with other ILDs [57, 59, 60]. Moreover, KL-6 is not only a marker for ILD, as elevated levels are also observed in cancer and tuberculosis [61-64]. In a small study including 14 IPF patients, serial increases in serum KL-6 levels were associated with poor survival [65]. Data obtained from a prospective study of 152 patients with idiopathic interstitial pneumonias and 67 patients with ILD associated with connective tissue disease showed that patients with a serum KL-6 level $>1,000 \mathrm{U} / \mathrm{ml}$ had a worse survival compared to those with lower levels [66]. These results support some usefulness for KL-6 as a potential prognostic biomarker.

\section{$S P-A$ and $S P-D$}

SP-A and SP-D are lipoprotein complexes synthesized in the lung mainly by AECII and secreted into a liquid layer lining the epithelium. In addition, they play an important role in the host defense against pathogens and are important constituents of the innate immunity of the lung [67]. SP-A and SP-D serum concentrations are increased in different pulmonary diseases including IPF. The mechanisms underlying serum elevation of these proteins likely include a combination of epithelial injury and breakdown together with an increased accumulation of AECII due to hyperplasia [68]. SP themselves might play a role in IPF pathogenesis. Aberrant SP processing by the endoplasmic reticulum has been involved in IPF pathogenesis, and genetic defects in genes encoding SPA1 and SP-A2 were associated with familial IPF [69-71]. With respect to their diagnostic and/or prognostic potential as biomarkers, both serum SP-A and SP-D are significantly elevated in IPF patients compared to healthy controls and patients with other ILDs [57, 72], although SP-D is also elevated in patients with nonspecific interstitial pneumonia [60]. Increased serum SP-A and SP-D levels obtained at the time of IPF diagnosis were independently associated with increased mortality [72-74]. More specifically, in a population of 52 IPF patients (mean follow-up time 11.4 months for the subjects who died and $>3$ years for the survivors), the concentration of SP-A and SP-D was within the normal range in the group of survivors $(n=10)$. Amongst the patients who died, only $25 \%$ had protein concentrations within the normal range [73]. In another study, the use of SP-A and SP-D was validated in a population of 142 IPF patients as a predictor of survival. They used a Cox proportional hazard model and found that an elevated concentration of SP-D (but not SP-A) correlates with increased death rate [72]. Finally, in a recent study in 82 IPF patients, increased serum SP-A (but not SP-D) levels were independently associated with death or lung transplantation within 1 year (HR 3.27 for each standard deviation increase, 95\% CI 1.49-7.17, $\mathrm{p}=$ 0.003) [74]. Thus, multiple studies have demonstrated that both SP-A and SP-D can distinguish IPF patients from those with other ILDs, and their levels are correlated with disease progression or mortality. However, large standard deviations of surfactant concentrations in the different studies and some yet unexplained differences between the populations and SP-A versus SP-D alterations preclude their present routine use as diagnostic and/ or prognostic biomarkers.

\section{Vascular Endothelial Growth Factor}

Many ILDs are associated with aberrant angiogenesis, but its role in the pathogenesis of fibrosis has not yet been fully elucidated [75]. In IPF, capillary density was increased in nonfibrotic usual interstitial pneumonia lesions, and AECII adjacent to these vessels were shown to produce vascular endothelial growth factor (VEGF)-B [76]. VEGF is a crucial factor for the homeostasis of the alveolus via the control of surfactant homeostasis and endothelial cell trophicity. The role of VEGF in lung fibrogenesis is poorly understood. Recent data demonstrate that exogenous VEGF-B can protect against pulmonary hypertension de- 
velopment while it increased fibrogenesis in an experimental model of fibrosis [77]. In a cohort of 41 IPF patients, an increase in serum VEGF-A was shown in patients with a high compared to patients with a low alveolar-arterial difference of oxygen ( 241.0 vs. $141.4 \mathrm{pg} / \mathrm{ml}$, respectively, $\mathrm{p}=$ $0.030)$ and compared to healthy volunteers $(162.2 \mathrm{pg} / \mathrm{ml}$, $\mathrm{p}=0.007$ ) [78]. Interestingly, serum VEGF levels did not correlate with baseline pulmonary function tests, but negatively correlated with changes in vital capacity during follow-up $(\mathrm{r}=-0.38, \mathrm{p}=0.044)$. IPF patients with serum VEGF levels above the median tended to have a shorter survival compared with patients with levels below the median. These data suggest that serum VEGF may reflect the severity of lung disease as well as predict declines in pulmonary function. Noteworthy, measuring the relative levels of the different VEGF isoforms might be very interesting given the gap of knowledge on the contribution of VEGF in IPF. Other markers of endothelial cell activation (such as VCAM-1) [79] or vascular remodeling (such as circulating endothelial cell precursors) [80] have been studied and might prove useful in the future.

\section{Matrix Metalloproteinases 1 and 7}

Matrix metalloproteinases (MMP) are a structurally and functionally related family of zinc-dependent proteases involved in the breakdown of ECM components and are thought to play a crucial role in ECM during pulmonary fibrosis [81]. MMP1, the most highly expressed interstitial collagenase, degrades fibrillar collagens, while MMP7, the smallest member of the MMP family, is capable of degrading multiple ECM components. Several lines of evidence point to MMP7 as a major player in IPF. MMP7 expression has been localized to the cell surface of AEC and alveolar macrophages from lung tissue of IPF patients, but it is not detected in the healthy lung. Accordingly, BALF MMP7 levels are higher in IPF patients than in healthy controls, suggesting that BALF levels may correlate with lung activity [82]. In the murine model of bleomycin-induced lung injury, genetic ablation of MMP7 is protective against pulmonary fibrosis [82-84]. On the other hand, a polymorphism in the promoter region of the gene encoding MMP1 is linked with IPF [85].

With respect to their biomarker potential, serum MMP1 and MMP7 levels are significantly elevated in IPF patients compared to healthy controls. MMP7 is not specific for IPF, as MMP7 expression in BALF and lung tissue is not significantly different between patients with IPF and other ILDs [84]. By contrast, combining the measurements of both serum MMP1 and MMP7 levels allowed distinguishing between IPF and hypersensitivity pneumonitis. The results of this study also showed that MMP7 concentrations were elevated in patients with subclinical ILD and negatively correlated with forced vital capacity and carbon monoxide diffusing capacity, suggesting that increased MMP7 concentration may be indicative of asymptomatic ILD and reflect disease progression [86]. In a recent larger study including 241 patients with IPF (140 derivation and 101 validation), the concentrations of 92 proteins were analyzed. The results showed that high concentrations of MMP7, ICAM-1, IL-8, VCAM-1 and S100A12 were significantly associated with mortality and/or disease progression. Of note, plasma MMP7 levels $>4.3 \mathrm{ng} / \mathrm{ml}$ were independently associated with increased mortality (adjusted HR 2.9, $\mathrm{p}=0.0013$ ) in the derivation cohort and tended towards an association in the validation cohort [79]. Altogether, these data suggest that MMP7 is unlikely to be a diagnostic marker, but it might be a prognostic tool, either alone or in combination, with other proteins.

\section{Osteopontin}

Osteopontin is a key proinflammatory cytokine involved in tissue repair [87]. Interest for this protein in lung diseases was ignited by the observation that osteopontin mRNA was upregulated in IPF lungs compared to healthy controls [83]. Accordingly, immunohistochemical staining demonstrated osteopontin expression by AEC and alveolar macrophages [88]. In the bleomycin model, osteopontin promotes migration, adhesion and proliferation of fibroblasts [89]. In vitro, osteopontin induces the growth rate and migration of fibroblasts and epithelial cells, and promotes ECM deposition [88].

In a small study including 17 patients with ILD ( 9 with sarcoidosis and 20 healthy controls), it was shown that plasma osteopontin concentrations were significantly higher in patients with ILD compared to the other patients. Despite the small study cohort, osteopontin levels of $300-380 \mathrm{ng} / \mathrm{ml}$ allowed to distinguish between patients with ILD and healthy controls with $100 \%$ sensitivity and specificity. However, there were no significant differences in plasma osteopontin levels between subjects with IPF and other ILDs. Plasma osteopontin was inversely correlated with $\mathrm{PaO}_{2}$, but not vital capacity or DLCO [90]. Overall, although the data are limited, the role of osteopontin in IPF pathogenesis, together with its remarkable sensitivity and specificity as a diagnostic marker for ILDs, suggests that further studies on this intriguing molecule are warranted and may reveal its novel function as a biomarker. 


\section{Circulating Fibrocytes}

Circulating fibrocytes do not directly constitute a biomarker reflective of epithelial injury. However, because epithelial injury modulates fibrocyte recruitment to the lungs, it would be neglectful not to mention the potential role of these cells as a biomarker. Fibrocytes are circulating bone marrow-derived mesenchymal progenitor cells that produce ECM components and have the ability to differentiate into fibroblasts and myofibroblasts during wound healing [91]. Fibrocytes have been detected in IPF tissue and are possibly attracted by the lungs via a mechanism involving the CXCL12-CXCR4 and CCL2-CCR2 axes [92, 93]. Their value as biomarker was assessed in a study involving a cohort of 58 patients with IPF. An increased proportion of circulating fibrocytes was found in patients compared to controls ( 2.72 vs. $1 \%$ of peripheral blood leukocytes, respectively) [49]. During acute exacerbation of IPF in 7 patients, fibrocyte numbers were significantly increased compared to 51 subjects with stable disease. Finally, in 3 IPF subjects who recovered from an acute exacerbation, fibrocyte counts returned to pre-exacerbation levels. Overall, it was shown that survival was worse in patients with $>5 \%$ circulating fibrocytes than in subjects with less fibrocytes. It is, however, noteworthy that the majority of this subset comprised patients with an acute exacerbation. Fibrocytes can be detected and quantified in BALF, but the number of alveolar fibrocytes was associated with less severe disease but not with a better outcome in IPF patients [94].

\section{Inflammation and IPF}

Although inflammation is not a prominent histopathological finding in IPF, there is evidence for some diffuse infiltration of immune cells in the fibrotic lung $[95,96]$. There is emerging evidence that inflammation/immune markers may provide useful information for patient stratification and to support innovative therapeutic strategies. Recent data indicate that activation of blood mononuclear cells might provide interesting markers for IPF outcome, as the level of expression of genes associated with the co-stimulatory signal during $\mathrm{T}$ cell activation (including CD28, ICOS, LCK and ITK) was shown to predict prognosis in two IPF cohorts [97].Circulating autoantibodies targeting periplakin, a desmosomal protein expressed by AEC, and HSP70, a chaperone protein, were proposed as promising prognostic markers for IPF [98, 99], suggesting that auto-immunity might play a role in the course of the disease. This is supported by the demonstration that abnormalities in B cells and B lymphocyte-stimulating factor are common in IPF patients and highly associated with disease manifestation and out- come [100]. Further, downregulation of CD28 on circulating CD4 $\mathrm{T}$ cells, a result of repeated antigen-driven proliferation, is associated with a poor outcome in IPF patients [101]. Plasma levels of periostin, a protein produced by monocytes and fibrocytes, particularly in the context of Th2 inflammation, but also by fibroblasts, are increased in IPF patients [102]. Serum levels of periostin in IPF were significantly higher than those of healthy subjects and patients with cryptogenic organizing pneumonia. Periostin levels in IPF patients were inversely correlated with their pulmonary functions [103].

\section{Conclusions}

Hallmarks of epithelial cell injury have the potential to serve as diagnostic and prognostic biomarkers for IPF and assist in its clinical management. However, although considerable efforts have been made in this field, with respect to both target identification and determination of their significance, there are still several limitations that preclude their broad use for investigational and/or clinical purposes. One pitfall is the limited number of patients included in the studies, which are often retrospective, in which the biomarkers have been tested. Most results, although promising, require confirmation in larger study cohorts. More prospective studies are obviously needed. Validation of the data would then raise the question of the added value of these biomarkers compared to the tests already in use in routine clinical practice. Another drawback is the paucity of longitudinal studies assessing the changes in candidate protein levels over time. They would be of crucial importance to determine whether a potential biomarker can truly be a surrogate for clinical endpoints such as changes in lung function, disease severity and progression, mortality and, in the case of clinical trials, response to therapy. The benefit of an individual biomarker as a diagnostic tool remains questionable: to date, the majority of biomarkers proposed do not allow the discrimination between different ILDs and they have poor specificity for IPF. Besides these considerations, which are an issue for biomarker studies in general [54, 104], there are some limitations in the use of these biomarkers derived from injured epithelial cells (i.e. from epithelial cell breakdown or hyperplasia). Indeed, modulation of their plasma levels is not only noted in other ILDs but also in pathological conditions such as malignancies. Of course, these diseases may very well coincide $[105,106]$. For instance, as discussed above, the levels of KL-6 increase in different cancers, such as adenocarcinoma of the lung. Thus, it may 
be tempting to hypothesize that the correlation between increases in KL-6 levels and a poor prognosis might partly reflect KL-6 increases in cancer and may not be attributable to IPF solely. These considerations raise further cautions which should to be taken in account, and the future will prove or refute the importance of these biomarkers in the comorbidities associated with IPF.

\section{Perspectives}

IPF is a complex disease involving aberrant cross talk of a broad panel of pulmonary resident and recruited cells. A better understanding of its pathogenic mechanisms not only provides targets for therapy, but also allows extrapolation of these insights from the bench to clinical practice, with the possibility to identify surrogate markers to monitor the disease course. To our knowledge, there are currently no broadly accepted and established clinical appli- cations for biomarkers of IPF. Only in Japan, KL-6, SP-A and SP-D are used in clinical practice, as they are considered to have good sensitivity and specificity to diagnose ILD, although their lack of specificity for IPF is acknowledged [107]. The combination of prospective validation of established markers, high-throughput technologies to perform unbiased screening and identification of new markers and prospective studies should allow to alleviate the limitations raised before. The results of studies like the PROFILE (Prospective Observation of Fibrosis in the Lung Clinical Endpoints) study (www.clinicaltrials.gov NCT01110694 and NCT01134822), a UK-based, multicenter, prospective cohort study of newly diagnosed IPF patients [108], which was launched in 2010, are eagerly awaited. Studies like this should help to unravel insights in IPF pathogenesis and provide tools allowing a more stratified and personalized approach to the classification, prognostication and treatment of IPF.

\section{References}

$>1$ King TE Jr, Pardo A, Selman M: Idiopathic pulmonary fibrosis. Lancet 2011;378:1949-1961.

$\checkmark 2$ Carter NJ: Pirfenidone: in idiopathic pulmonary fibrosis. Drugs 2011;71:1721-1732.

$\checkmark 3$ Poletti V, Ravaglia C, Buccioli M, Tantalocco P, Piciucchi S, Dubini A, Carloni A, Chilosi M, Tomassetti S: Idiopathic pulmonary fibrosis: diagnosis and prognostic evaluation. Respiration 2013;86:5-12.

-4 American Thoracic Society. Idiopathic pulmonary fibrosis: diagnosis and treatment. International consensus statement. American Thoracic Society (ATS), and the European Respiratory Society (ERS). Am J Respir Crit Care Med 2000;161:646-664.

$\checkmark 5$ Raghu G, Collard HR, Egan JJ, Martinez FJ, Behr J, Brown KK, Colby TV, Cordier JF, Flaherty KR, Lasky JA, Lynch DA, Ryu JH, Swigris JJ, Wells AU, Ancochea J, Bouros D, Carvalho C, Costabel U, Ebina M, Hansell DM, Johkoh T, Kim DS, King TE Jr, Kondoh Y, Myers J, Muller NL, Nicholson AG, Richeldi L, Selman M, Dudden RF, Griss BS, Protzko SL, Schunemann HJ, ATS/ERS/JRS/ALAT Committee on Idiopathic Pulmonary Fibrosis: An official ATS/ERS/JRS/ALAT statement: idiopathic pulmonary fibrosis: evidence-based guidelines for diagnosis and management. Am J Respir Crit Care Med 2011;183:788-824.

$\checkmark 6$ American Thoracic Society/European Respiratory Society International Multidisciplinary Consensus Classification of the Idiopathic Interstitial Pneumonias. This joint statement of the American Thoracic Society (ATS), and the European Respiratory Society (ERS) was adopted by the ATS Board of Directors, June 2001 and by the ERS Executive Committee, June 2001. Am J Respir Crit Care Med 2002; 165:277-304.

7 Travis WD, Costabel U, Hansell DM, King TE Jr, Lynch DA, Nicholson AG, Ryerson CJ, Ryu JH, Selman M, Wells AU, Behr J, Bouros D, Brown KK, Colby TV, Collard HR, Cordeiro CR, Cottin V, Crestani B, Drent M, Dudden RF, Egan J, Flaherty K, Hogaboam C, Inoue Y, Johkoh T, Kim DS, Kitaichi M, Loyd J, Martinez FJ, Myers J, Protzko S, Raghu G, Richeldi L, Sverzellati N, Swigris J, Valeyre D, ATS/ ERS Committee on Idiopathic Interstitial Pneumonias: An official American Thoracic Society/European Respiratory Society statement: update of the international multidisciplinary classification of the idiopathic interstitial pneumonias. Am J Respir Crit Care Med 2013;188:733-748.

$>8$ van den Blink B, Wijsenbeek MS, Hoogsteden HC: Serum biomarkers in idiopathic pulmonary fibrosis. Pulm Pharmacol Ther 2010;23: 515-520.

$\checkmark 9$ Ley B, Collard HR, King TE Jr: Clinical course and prediction of survival in idiopathic pulmonary fibrosis. Am J Respir Crit Care Med 2011;183:431-440.

10 Ley B, Ryerson CJ, Vittinghoff E, Ryu JH, Tomassetti S, Lee JS, Poletti V, Buccioli M, Elicker BM, Jones KD, King TE Jr, Collard HR: A multidimensional index and staging system for idiopathic pulmonary fibrosis. Ann Intern Med 2012;156:684-691.
11 Raghu G, Anstrom KJ, King TE Jr, Lasky JA, Martinez FJ: Prednisone, azathioprine, and $\mathrm{N}$-acetylcysteine for pulmonary fibrosis. N Engl J Med 2012;366:1968-1977.

-12 Selman M, King TE, Pardo A: Idiopathic pulmonary fibrosis: prevailing and evolving hypotheses about its pathogenesis and implications for therapy. Ann Intern Med 2001;134: 136-151.

13 Kasper M, Haroske G: Alterations in the alveolar epithelium after injury leading to pulmonary fibrosis. Histol Histopathol 1996;11: 463-483.

14 Katzenstein AL: Pathogenesis of 'fibrosis' in interstitial pneumonia: an electron microscopic study. Hum Pathol 1985;16:1015-1024.

15 Kawanami O, Ferrans VJ, Crystal RG: Structure of alveolar epithelial cells in patients with fibrotic lung disorders. Lab Invest 1982;46: 39-53.

16 Adamson IY, Bowden DH: Bleomycin-induced injury and metaplasia of alveolar type 2 cells. Relationship of cellular responses to drug presence in the lung. Am J Pathol 1979; 96:531-544.

17 Hagimoto N, Kuwano K, Miyazaki H, Kunitake R, Fujita M, Kawasaki M, Kaneko Y, Hara N: Induction of apoptosis and pulmonary fibrosis in mice in response to ligation of Fas antigen. Am J Respir Cell Mol Biol 1997;17:272-278.

$>18$ Wang R, Ibarra-Sunga O, Verlinski L, Pick R, Uhal BD: Abrogation of bleomycin-induced epithelial apoptosis and lung fibrosis by captopril or by a caspase inhibitor. Am J Physiol Lung Cell Mol Physiol 2000;279:L143-L151. 
19 Morishima Y, Nomura A, Uchida Y, Noguchi Y, Sakamoto T, Ishii Y, Goto Y, Masuyama K, Zhang MJ, Hirano K, Mochizuki M, Ohtsuka M, Sekizawa K: Triggering the induction of myofibroblast and fibrogenesis by airway epithelial shedding. Am J Respir Cell Mol Biol 2001;24:1-11.

20 Marchand-Adam S, Plantier L, Bernuau D, Legrand A, Cohen M, Marchal J, Soler P, Leseche G, Mal H, Aubier M, Dehoux M, Crestani B: Keratinocyte growth factor expression by fibroblasts in pulmonary fibrosis: poor response to interleukin-1beta. Am J Respir Cell Mol Biol 2005;32:470-477.

-21 Marchand-Adam S, Fabre A, Mailleux AA, Marchal J, Quesnel C, Kataoka H, Aubier M, Dehoux M, Soler P, Crestani B: Defect of prohepatocyte growth factor activation by fibroblasts in idiopathic pulmonary fibrosis. Am J Respir Crit Care Med 2006;174:58-66.

22 Atabai K, Ishigaki M, Geiser T, Ueki I, Matthay MA, Ware LB: Keratinocyte growth factor can enhance alveolar epithelial repair by nonmitogenic mechanisms. Am J Physiol Lung Cell Mol Physiol 2002;283:L163-L169.

-23 Dohi M, Hasegawa T, Yamamoto K, Marshall BC: Hepatocyte growth factor attenuates collagen accumulation in a murine model of pulmonary fibrosis. Am J Respir Crit Care Med 2000;162:2302-2307.

24 Kim HJ, Sammak PJ, Ingbar DH: Hepatocyte growth factor stimulates migration of type II alveolar epithelial cells on the provisional matrix proteins fibronectin and fibrinogen. Chest 1999;116:94S-95S.

-25 Sisson TH, Mendez M, Choi K, Subbotina N, Courey A, Cunningham A, Dave A, Engelhardt JF, Liu X, White ES, Thannickal VJ, Moore BB, Christensen PJ, Simon RH: Targeted injury of type II alveolar epithelial cells induces pulmonary fibrosis. Am J Respir Crit Care Med 2010;181:254-263.

-26 Plantier L, Crestani B, Wert SE, Dehoux M, Zweytick B, Guenther A, Whitsett JA: Ectopic respiratory epithelial cell differentiation in bronchiolised distal airspaces in idiopathic pulmonary fibrosis. Thorax 2011;66:651-657.

-27 Beers MF, Morrisey EE: The three R's of lung health and disease: repair, remodeling, and regeneration. J Clin Invest 2011;121:20652073.

28 Bhattacharya J, Matthay MA: Regulation and repair of the alveolar-capillary barrier in acute lung injury. Annu Rev Physiol 2013;75:593615.

29 Fehrenbach H: Alveolar epithelial type II cell: defender of the alveolus revisited. Respir Res 2001;2:33-46.

30 Matthay MA: Function of the alveolar epithelial barrier under pathologic conditions. Chest 1994;105:67S-74S.

- 31 Barkauskas CE, Cronce MJ, Rackley CR, Bowie EJ, Keene DR, Stripp BR, Randell SH, Noble PW, Hogan BL: Type 2 alveolar cells are stem cells in adult lung. J Clin Invest 2013;123: 3025-3036.
32 Adamson IY, Bowden DH: Derivation of type 1 epithelium from type 2 cells in the developing rat lung. Lab Invest 1975;32:736-745.

33 Serrano-Mollar A, Nacher M, Gay-Jordi G, Closa D, Xaubet A, Bulbena O: Intratracheal transplantation of alveolar type II cells reverses bleomycin-induced lung fibrosis. Am J Respir Crit Care Med 2007;176:1261-1268.

34 Tsakiri KD, Cronkhite JT, Kuan PJ, Xing C, Raghu G, Weissler JC, Rosenblatt RL, Shay JW, Garcia CK: Adult-onset pulmonary fibrosis caused by mutations in telomerase. Proc Natl Acad Sci USA 2007; 104:7552-7557.

- 35 Alder JK, Chen JJ, Lancaster L, Danoff S, Su SC, Cogan JD, Vulto I, Xie M, Qi X, Tuder RM, Phillips JA 3rd, Lansdorp PM, Loyd JE, Armanios MY: Short telomeres are a risk factor for idiopathic pulmonary fibrosis. Proc Natl Acad Sci USA 2008;105:13051-13056.

- 36 Diaz de Leon A, Cronkhite JT, Katzenstein AL, Godwin JD, Raghu G, Glazer CS, Rosenblatt RL, Girod CE, Garrity ER, Xing C, Garcia CK: Telomere lengths, pulmonary fibrosis and telomerase (TERT) mutations. PloS One 2010;5:e10680.

37 Jin HL, Dong JC: Pathogenesis of idiopathic pulmonary fibrosis: from initial apoptosis of epithelial cells to lung remodeling? Chin Med J (Engl) 2011;124:4330-4338.

38 Kim KK, Kugler MC, Wolters PJ, Robillard L, Galvez MG, Brumwell AN, Sheppard D, Chapman HA: Alveolar epithelial cell mesenchymal transition develops in vivo during pulmonary fibrosis and is regulated by the extracellular matrix. Proc Natl Acad Sci USA 2006;103:13180-13185.

39 Kim KK, Wei Y, Szekeres C, Kugler MC, Wolters PJ, Hill ML, Frank JA, Brumwell AN, Wheeler SE, Kreidberg JA, Chapman HA: Epithelial cell $\alpha_{3} \beta_{1}$ integrin links $\beta$-catenin and Smad signaling to promote myofibroblast formation and pulmonary fibrosis. J Clin Invest 2009;119:213-224.

40 Tanjore H, Xu XC, Polosukhin VV, Degryse AL, Li B, Han W, Sherrill TP, Plieth D, Neilson EG, Blackwell TS, Lawson WE: Contribution of epithelial-derived fibroblasts to bleomycin-induced lung fibrosis. Am J Respir Crit Care Med 2009; 180:657-665.

41 Rock JR, Barkauskas CE, Cronce MJ, Xue Y, Harris JR, Liang J, Noble PW, Hogan BL: Multiple stromal populations contribute to pulmonary fibrosis without evidence for epithelial to mesenchymal transition. Proc Natl Acad Sci USA 2011;108:E1475-E1483.

42 Moore BB, Peters-Golden M, Christensen PJ, Lama V, Kuziel WA, Paine R 3rd, Toews GB: Alveolar epithelial cell inhibition of fibroblast proliferation is regulated by MCP-1/CCR2 and mediated by PGE2. Am J Physiol Lung Cell Mol Physiol 2003;284:L342-L349.

43 Lama V, Moore BB, Christensen P, Toews GB, Peters-Golden M: Prostaglandin E2 synthesis and suppression of fibroblast proliferation by alveolar epithelial cells is cyclooxygenase-2-dependent. Am J Respir Cell Mol Biol 2002;27:752-758.
44 Bozyk PD, Moore BB: Prostaglandin E2 and the pathogenesis of pulmonary fibrosis. Am J Respir Cell Mol Biol 2011;45:445-452.

45 Maher TM, Evans IC, Bottoms SE, Mercer PF, Thorley AJ, Nicholson AG, Laurent GJ, Tetley TD, Chambers RC, McAnulty RJ: Diminished prostaglandin E2 contributes to the apoptosis paradox in idiopathic pulmonary fibrosis. Am J Respir Crit Care Med 2010;182:73-82.

46 Mercer PF, Johns RH, Scotton CJ, Krupiczojc MA, Konigshoff M, Howell DC, McAnulty RJ, Das A, Thorley AJ, Tetley TD, Eickelberg $\mathrm{O}$, Chambers RC: Pulmonary epithelium is a prominent source of proteinase-activated receptor-1-inducible CCL2 in pulmonary fibrosis. Am J Respir Crit Care Med 2009;179:414425.

47 Scotton CJ, Krupiczojc MA, Konigshoff M, Mercer PF, Lee YC, Kaminski N, Morser J, Post JM, Maher TM, Nicholson AG, Moffatt JD, Laurent GJ, Derian CK, Eickelberg O, Chambers RC: Increased local expression of coagulation factor $\mathrm{X}$ contributes to the fibrotic response in human and murine lung injury. J Clin Invest 2009;119:2550-2563.

48 Phillips RJ, Burdick MD, Hong K, Lutz MA, Murray LA, Xue YY, Belperio JA, Keane MP, Strieter RM: Circulating fibrocytes traffic to the lungs in response to CXCL12 and mediate fibrosis. J Clin Invest 2004;114:438-446.

49 Moeller A, Gilpin SE, Ask K, Cox G, Cook D, Gauldie J, Margetts PJ, Farkas L, Dobranowski J, Boylan C, O’Byrne PM, Strieter RM, Kolb M: Circulating fibrocytes are an indicator of poor prognosis in idiopathic pulmonary fibrosis. Am J Respir Crit Care Med 2009;179:588-594.

50 Gunther A, Korfei M, Mahavadi P, von der Beck D, Ruppert C, Markart P: Unravelling the progressive pathophysiology of idiopathic pulmonary fibrosis. Eur Respir Rev 2012;21: 152-160.

51 Fung ET, Wright GL Jr, Dalmasso EA: Proteomic strategies for biomarker identification: progress and challenges. Curr Opin $\mathrm{Mol}$ Ther 2000;2:643-650.

52 Sackett DL, Haynes RB: The architecture of diagnostic research. BMJ 2002;324:539-541.

53 Biomarkers Definitions Working Group: Biomarkers and surrogate endpoints: preferred definitions and conceptual framework. Clin Pharmacol Ther 2001;69:89-95.

54 Doyle TJ, Pinto-Plata V, Morse D, Celli BR, Rosas IO: The expanding role of biomarkers in the assessment of smoking-related parenchymal lung diseases. Chest 2012;142:10271034.

55 Vij R, Noth I: Peripheral blood biomarkers in idiopathic pulmonary fibrosis. Transl Res 2012;159:218-227.

56 Bandoh S, Fujita J, Ohtsuki Y, Ueda Y, Hojo S, Tokuda M, Dobashi H, Kurata N, Yoshinouchi T, Kohno N, Takahara J: Sequential changes of KL-6 in sera of patients with interstitial pneumonia associated with polymyositis/dermatomyositis. Ann Rheum Dis 2000; 59:257-262. 
57 Ishii H, Mukae H, Kadota J, Kaida H, Nagata T, Abe K, Matsukura S, Kohno S: High serum concentrations of surfactant protein A in usual interstitial pneumonia compared with nonspecific interstitial pneumonia. Thorax 2003; 58:52-57.

58 Ohshimo S, Yokoyama A, Hattori N, Ishikawa N, Hirasawa Y, Kohno N: KL-6, a human MUC1 mucin, promotes proliferation and survival of lung fibroblasts. Biochem Biophys Res Commun 2005;338:1845-1852.

59 Hant FN, Ludwicka-Bradley A, Wang HJ, Li N, Elashoff R, Tashkin DP, Silver RM: Surfactant protein D and KL-6 as serum biomarkers of interstitial lung disease in patients with scleroderma. J Rheumatol 2009;36:773-780.

60 Ichiyasu H, Ichikado K, Yamashita A, Iyonaga K, Sakamoto O, Suga M, Kohrogi H: Pneumocyte biomarkers KL-6 and surfactant protein D reflect the distinct findings of high-resolution computed tomography in nonspecific interstitial pneumonia. Respiration 2012;83: 190-197.

-61 Snijdewint FG, von Mensdorff-Pouilly S, Karuntu-Wanamarta AH, Verstraeten AA, Livingston PO, Hilgers J, Kenemans P: Antibody-dependent cell-mediated cytotoxicity can be induced by MUC1 peptide vaccination of breast cancer patients. Int J Cancer 2001;93: 97-106.

-62 Hiraga Y, Tanaka S, Haruma K, Yoshihara M, Sumii K, Kajiyama G, Shimamoto F, Kohno $\mathrm{N}$ : Immunoreactive MUC1 expression at the deepest invasive portion correlates with prognosis of colorectal cancer. Oncology 1998;55: 307-319.

-63 Hirasawa Y, Kohno N, Yokoyama A, Kondo K, Hiwada K, Miyake M: Natural autoantibody to MUC1 is a prognostic indicator for non-small cell lung cancer. Am J Respir Crit Care Med 2000;161:589-594.

-64 Inoue Y, Nishimura K, Shiode M, Akutsu H, Hamada H, Fujioka S, Fujino S, Yokoyama A, Kohno N, Hiwada K: Evaluation of serum KL-6 levels in patients with pulmonary tuberculosis. Tuber Lung Dis 1995;76:230-233.

-65 Yokoyama A, Kohno N, Hamada H, Sakatani M, Ueda E, Kondo K, Hirasawa Y, Hiwada K: Circulating KL-6 predicts the outcome of rapidly progressive idiopathic pulmonary fibrosis. Am J Respir Crit Care Med 1998;158: 1680-1684.

66 Satoh H, Kurishima K, Ishikawa H, Ohtsuka M: Increased levels of KL-6 and subsequent mortality in patients with interstitial lung diseases. J Intern Med 2006;260:429-434.

67 Goerke J: Pulmonary surfactant: functions and molecular composition. Biochim Biophys Acta 1998;1408:79-89.

-68 Cheng IW, Ware LB, Greene KE, Nuckton TJ, Eisner MD, Matthay MA: Prognostic value of surfactant proteins A and D in patients with acute lung injury. Crit Care Med 2003;31:2027.
9 Lawson WE, Crossno PF, Polosukhin VV, Roldan J, Cheng DS, Lane KB, Blackwell TR, Xu C, Markin C, Ware LB, Miller GG, Loyd JE, Blackwell TS: Endoplasmic reticulum stress in alveolar epithelial cells is prominent in IPF: association with altered surfactant protein processing and herpesvirus infection. Am J Physiol Lung Cell Mol Physiol 2008; 294:L1119-L1126.

70 Wang Y, Kuan PJ, Xing C, Cronkhite JT, Torres F, Rosenblatt RL, DiMaio JM, Kinch LN, Grishin NV, Garcia CK: Genetic defects in surfactant protein A2 are associated with pulmonary fibrosis and lung cancer. Am J Hum Genet 2009;84:52-59.

71 Zhang X, Jiang J, Chen WJ, Su LX, Xie LX: Genetic characterization of a Chinese family with familial idiopathic pulmonary fibrosis. Chin Med J (Engl) 2012;125:1945-1951.

72 Greene KE, King TE Jr, Kuroki Y, Bucher-Bartelson B, Hunninghake GW, Newman LS, Nagae H, Mason RJ: Serum surfactant proteins$\mathrm{A}$ and -D as biomarkers in idiopathic pulmonary fibrosis. Eur Respir J 2002;19:439-446.

73 Takahashi H, Fujishima T, Koba H, Murakami S, Kurokawa K, Shibuya Y, Shiratori M, Kuroki Y, Abe S: Serum surfactant proteins A and $\mathrm{D}$ as prognostic factors in idiopathic pulmonary fibrosis and their relationship to disease extent. Am J Respir Crit Care Med 2000; 162:1109-1114.

74 Kinder BW, Brown KK, McCormack FX, Ix JH, Kervitsky A, Schwarz MI, King TE Jr: Serum surfactant protein-A is a strong predictor of early mortality in idiopathic pulmonary fibrosis. Chest 2009;135:1557-1563.

75 Hanumegowda C, Farkas L, Kolb M: Angiogenesis in pulmonary fibrosis: too much or not enough? Chest 2012;142:200-207.

76 Ebina M, Shimizukawa M, Shibata N, Kimura Y, Suzuki T, Endo M, Sasano H, Kondo T, Nukiwa T: Heterogeneous increase in CD34positive alveolar capillaries in idiopathic pulmonary fibrosis. Am J Respir Crit Care Med 2004;169:1203-1208.

77 Farkas L, Farkas D, Ask K, Moller A, Gauldie J, Margetts P, Inman M, Kolb M: VEGF ameliorates pulmonary hypertension through inhibition of endothelial apoptosis in experimental lung fibrosis in rats. J Clin Invest 2009; 119:1298-1311.

78 Ando M, Miyazaki E, Ito T, Hiroshige S, Nureki SI, Ueno T, Takenaka R, Fukami T, Kumamoto T: Significance of serum vascular endothelial growth factor level in patients with idiopathic pulmonary fibrosis. Lung 2010; 188:247-252.

79 Richards TJ, Kaminski N, Baribaud F, Flavin S, Brodmerkel C, Horowitz D, Li K, Choi J, Vuga LJ, Lindell KO, Klesen M, Zhang Y, Gibson KF: Peripheral blood proteins predict mortality in idiopathic pulmonary fibrosis. Am J Respir Crit Care Med 2012;185: 67-76.
0 Smadja DM, Mauge L, Nunes H, d'Audigier C, Juvin K, Borie R, Carton Z, Bertil S, Blanchard A, Crestani B, Valeyre D, Gaussem $P$, Israel-Biet D: Imbalance of circulating endothelial cells and progenitors in idiopathic pulmonary fibrosis. Angiogenesis 2013;16: 147-157.

81 Oikonomidi S, Kostikas K, Tsilioni I, Tanou K, Gourgoulianis KI, Kiropoulos TS: Matrix metalloproteinases in respiratory diseases: from pathogenesis to potential clinical implications. Curr Med Chem 2009;16:12141228.

82 Fujishima S, Shiomi T, Yamashita S, Yogo Y, Nakano Y, Inoue T, Nakamura M, Tasaka S, Hasegawa N, Aikawa N, Ishizaka A, Okada $\mathrm{Y}$ : Production and activation of matrix metalloproteinase 7 (matrilysin 1) in the lungs of patients with idiopathic pulmonary fibrosis. Arch Pathol Lab Med 2010;134:11361142.

83 Zuo F, Kaminski N, Eugui E, Allard J, Yakhini Z, Ben-Dor A, Lollini L, Morris D, Kim Y, DeLustro B, Sheppard D, Pardo A, Selman M, Heller RA: Gene expression analysis reveals matrilysin as a key regulator of pulmonary fibrosis in mice and humans. Proc Natl Acad Sci USA 2002;99:6292-6297.

84 Vuorinen K, Myllarniemi M, Lammi L, Piirila P, Rytila P, Salmenkivi K, Kinnula VL: Elevated matrilysin levels in bronchoalveolar lavage fluid do not distinguish idiopathic pulmonary fibrosis from other interstitial lung diseases. APMIS 2007;115:969-975.

85 Checa M, Ruiz V, Montano M, VelazquezCruz R, Selman M, Pardo A: MMP-1 polymorphisms and the risk of idiopathic pulmonary fibrosis. Hum Genet 2008;124:465-472.

-86 Rosas IO, Richards TJ, Konishi K, Zhang Y, Gibson K, Lokshin AE, Lindell KO, Cisneros J, Macdonald SD, Pardo A, Sciurba F, Dauber J, Selman M, Gochuico BR, Kaminski N: MMP1 and MMP7 as potential peripheral blood biomarkers in idiopathic pulmonary fibrosis. PLoS Med 2008;5:e93.

87 O'Regan A: The role of osteopontin in lung disease. Cytokine Growth Factor Rev 2003;14: 479-488.

88 Pardo A, Gibson K, Cisneros J, Richards TJ, Yang Y, Becerril C, Yousem S, Herrera I, Ruiz V, Selman M, Kaminski N: Up-regulation and profibrotic role of osteopontin in human idiopathic pulmonary fibrosis. PLoS Med 2005; 2:e251.

-89 Takahashi F, Takahashi K, Okazaki T, Maeda K, Ienaga H, Maeda M, Kon S, Uede T, Fukuchi Y: Role of osteopontin in the pathogenesis of bleomycin-induced pulmonary fibrosis. Am J Respir Cell Mol Biol 2001;24:264-271.

90 Kadota J, Mizunoe S, Mito K, Mukae H, Yoshioka S, Kawakami K, Koguchi Y, Fukushima K, Kon S, Kohno S, Saito A, Uede T, Nasu M: High plasma concentrations of osteopontin in patients with interstitial pneumonia. Respir Med 2005;99:111-117. 
91 Mehrad B, Burdick MD, Zisman DA, Keane MP, Belperio JA, Strieter RM: Circulating peripheral blood fibrocytes in human fibrotic interstitial lung disease. Biochem Biophys Res Commun 2007;353:104-108.

92 Andersson-Sjoland A, de Alba CG, Nihlberg K, Becerril C, Ramirez R, Pardo A, Westergren-Thorsson G, Selman M: Fibrocytes are a potential source of lung fibroblasts in idiopathic pulmonary fibrosis. Int J Biochem Cell Biol 2008;40:2129-2140.

93 Mehrad B, Burdick MD, Strieter RM: Fibrocyte CXCR4 regulation as a therapeutic target in pulmonary fibrosis. Int J Biochem Cell Biol 2009;41:1708-1718.

\$4 Borie R, Quesnel C, Phin S, Debray MP, Marchal-Somme J, Tiev K, Bonay M, Fabre A, Soler P, Dehoux M, Crestani B: Detection of alveolar fibrocytes in idiopathic pulmonary fibrosis and systemic sclerosis. PloS One 2013; 8:e53736.

$\$ 95$ Marchal-Somme J, Uzunhan Y, MarchandAdam S, Kambouchner M, Valeyre D, Crestani B, Soler P: Dendritic cells accumulate in human fibrotic interstitial lung disease. Am J Respir Crit Care Med 2007;176:1007-1014.

96 Marchal-Somme J, Uzunhan Y, MarchandAdam S, Valeyre D, Soumelis V, Crestani B, Soler P: Cutting edge: nonproliferating mature immune cells form a novel type of organized lymphoid structure in idiopathic pulmonary fibrosis. J Immunol 2006;176:57355739.
-97 Herazo-Maya JD, Noth I, Duncan SR, Kim S, Ma SF, Tseng GC, Feingold E, JuanGuardela BM, Richards TJ, Lussier Y, Huang Y, Vij R, Lindell KO, Xue J, Gibson KF, Shapiro SD, Garcia JG, Kaminski N: Peripheral blood mononuclear cell gene expression profiles predict poor outcome in idiopathic pulmonary fibrosis. Sci Transl Med 2013;5: 205 ra136.

98 Taille C, Grootenboer-Mignot S, Boursier C, Michel L, Debray MP, Fagart J, Barrientos L, Mailleux A, Cigna N, Tubach F, MarchalSomme J, Soler P, Chollet-Martin S, Crestani B: Identification of periplakin as a new target for autoreactivity in idiopathic pulmonary fibrosis. Am J Respir Crit Care Med 2011;183:759-766.

99 Kahloon RA, Xue J, Bhargava A, Csizmadia E, Otterbein L, Kass DJ, Bon J, Soejima M, Levesque MC, Lindell KO, Gibson KF, Kaminski N, Banga G, Oddis CV, Pilewski JM, Sciurba FC, Donahoe M, Zhang Y, Duncan SR: Patients with idiopathic pulmonary fibrosis with antibodies to heat shock protein 70 have poor prognoses. Am J Respir Crit Care Med 2013;187:768-775.

100 Xue J, Kass DJ, Bon J, Vuga L, Tan J, Csizmadia E, Otterbein L, Soejima M, Levesque MC, Gibson KF, Kaminski N, Pilewski JM, Donahoe M, Sciurba FC, Duncan SR: Plasma B lymphocyte stimulator and B cell differentiation in idiopathic pulmonary fibrosis patients. J Immunol 2013;191:20892095.

101 Gilani SR, Vuga LJ, Lindell KO, Gibson KF, Xue J, Kaminski N, Valentine VG, Lindsay EK, George MP, Steele C, Duncan SR: CD28 down-regulation on circulating CD4 T-cells is associated with poor prognoses of patients with idiopathic pulmonary fibrosis. PloS One 2010;5:e8959.
02 Naik PK, Bozyk PD, Bentley JK, Popova AP, Birch CM, Wilke CA, Fry CD, White ES, Sisson TH, Tayob N, Carnemolla B, Orecchia P, Flaherty KR, Hershenson MB, Murray S, Martinez FJ, Moore BB: Periostin promotes fibrosis and predicts progression in patients with idiopathic pulmonary fibrosis. Am J Physiol Lung Cell Mol Physiol 2012; 303:L1046-L1056.

103 Okamoto M, Hoshino T, Kitasato Y, Sakazaki Y, Kawayama T, Fujimoto K, Ohshima K, Shiraishi H, Uchida M, Ono J, Ohta S, Kato S, Izuhara K, Aizawa H: Periostin, a matrix protein, is a novel biomarker for idiopathic interstitial pneumonias. Eur Respir J 2011;37:1119-1127.

104 Sin DD, Vestbo J: Biomarkers in chronic obstructive pulmonary disease. Proc Am Thorac Soc 2009;6:543-545.

105 Daniels CE, Jett JR: Does interstitial lung disease predispose to lung cancer? Curr Opin Pulm Med 2005;11:431-437.

106 Vancheri C: Common pathways in idiopathic pulmonary fibrosis and cancer. Eur Respir Rev 2013;22:265-272.

107 Huang HB, Peng XN, Nakajima J: Advances in the study of biomarkers of idiopathic pulmonary fibrosis in Japan. Biosci Trends 2013; 7:172-177.

108 Maher TM: PROFILEing idiopathic pulmonary fibrosis: rethinking biomarker discovery. Eur Respir Rev 2013;22:148-152. 